\title{
Comparison of Muscle Activities of Trunk and Lower Limb during Bow and Squat Exercises
}

\author{
Ji-won Shon' ${ }^{1}$ Hyung-won Lim² \\ 'Department of Physical Therapy, Graduate School, Hanseo University, Seosan; ${ }^{2}$ Department of Physical Therapy, Dankook University, Cheonan
}

Purpose: The purposes of this study were to examine muscle activities of trunk and lower limb during squat and 108 bows exercises and to provide objective data for establishing a training method for improving muscle strength of trunk and lower limb.

Methods: Twenty normal healthy subjects participated in this study. Each exercise was divided into five periods. Muscle activities of trunk and lower limb in each period of both 108 bows and squat exercises were measured and analyzed by independent t-test.

Results: In starting, mid-flexion, mid-extension, and end period muscle activities obtained from 108 bows exercise were significantly higher than those from squat exercise. However, in the final flexion period, muscle activities of multifidus, elector spinae, rectus femoris, biceps femoris, and tibialis anterior from squat exercise were significantly higher than those from bow exercise.

Conclusion: In this study, high muscle activities in most muscles of trunk and lower limb were observed from all periods of 108 bows exercise except the final flexion period. Therefore, it is likely that 108 bows exercise rather than squat exercise is more suitable for high strength exercise to improve muscle strength of trunk and lower limb and thus will be applicable for strengthening muscles of trunk and lower limb of patients.

Keywords: 108 Bows exercise, Squat, Muscle activation

서 론

스쿼트(squat) 운동은 하지 전체의 근육을 단련시킬 뿐만 아니라 고 관절, 슬관절, 그리고 족관절 주변 근육을 강화시키는 매우 중요한 운동으로 인식돼 왔다. 임상에서는 체간과 하지의 근력을 강화하기 위한 방법으로 닫힌사슬 운동(closed kinematic chains) 동작을 응용 한 치료적 운동을 적용하고 있다. 닫힌사슬 운동은 체중을 지지한 자 세에서 이루어지는 운동으로 열린사슬 운동(open kinematic chains) 보다 체중에 의해 관절면이 일치되어 관절 내 구조물이나 관절 주위 의 고유수용성감각을 효율적으로 자극하며, 안정성을 증가시킨다. 또한 자세를 유지하기 위해 주동근과 길항근의 동시수축을 촉진한 다. ${ }^{2}$

절(bow)은 불교의 4 대 수행방법 중 하나인 108 배로 잘 알려져 있다. 108 배는 108 번 동안 절 동작을 반복하면서 몸과 마음을 스스로 다스 리고 정신적인 평화와 행복을 찾아 깨달음을 이루는 것을 목표로 한 다. 절 운동과 스쿼트는 공간의 제약 없이 언제나 수행 가능한 운동 방법으로 체중을 지지한 자세에서 고관절, 슬관절, 그리고 족관절의
움직임을 동시에 발생시키는 닫힌사슬 운동이다. ${ }^{3,4}$ 대부분의 전방십 자인대 재활프로토콜에서 체중부하운동이 강조됨에도 불구하고, 일반적으로 근력강화 훈련이나 대퇴사두근의 근력을 평가하기 위하 여 등속성 슬관절 신전운동을 수술 후 8 주에서 6 개월까지 사용하는 것이 좋다고 보고하였다. ${ }^{5-8} \operatorname{Jan}$ 등 ${ }^{9}$ 은 무릎 골관절염 환자를 대상으 로 체중부하 운동과 비체중부하 운동의 효과를 비교한 연구에서 비 체중부하 운동만으로도 기능 및 근력 강화를 향상시키기에 충분하 다고 하였다. 슬개대퇴동통증후군 환자에게 닫힌사슬 운동을 적용 한 연구에서는 관절의 안정성과 근력 및 균형능력, 고유수용성감각 이 향상되었다고 보고하였다.10,11 이처럼 아직 무릎 질환에 대한 근력 증가를 위한 최적의 중재방법에 대한 합의가 없다. ${ }^{12}$

절운동과 스쿼트는 같은 닫힌사슬 운동으로 분류되며, 기립에서 앉았다 일어서기를 반복하는 체간과 하지의 근력강화 운동이다. 앉 기와 일어서기를 반복하는 운동은 사지의 움직임과 자세를 조절하 기 위해 관절주위의 다분절 근육이 원심성 수축과 구심성 수축을 반 복하고 이에 따라 골반 중심의 안정성을 높이는 기능적 훈련효과가 있으며, 체간과 하지의 근육 특히 척추기립근과 대퇴사두근, 슬괵근,
Received Mar 22, 2016 Revised Apr 17, 2016

Accepted Apr 18, 2016

Corresponding author Hyung-won Lim

E-mail movt12@hanmail.net
Copylight (C) 2016 The Korea Society of Physical Therapy

This is an Open Access article distribute under the terms of the Creative Commons Attribution Non-commercial License (Http:// creativecommons.org/license/by-nc/3.0.) which permits unrestricted non-commercial use, distribution, and reproduction in any medium, provided the original work is properly cited. 
Table 1. The comparison of muscle activities of trunk and lower limb in each period during squat and bow exercises

\begin{tabular}{|c|c|c|c|c|c|}
\hline \multirow{2}{*}{ Period } & \multirow{2}{*}{ Variable } & \multicolumn{2}{|c|}{ Exercise (\%) } & \multirow{2}{*}{$\mathrm{t}$} & \multirow{2}{*}{$\mathrm{p}$} \\
\hline & & Bow & Squat & & \\
\hline \multirow[t]{7}{*}{ Start } & MT & $17.58 \pm 7.26$ & $10.80 \pm 5.69$ & -3.282 & $0.002^{*}$ \\
\hline & ES & $11.40 \pm 6.87$ & $6.37 \pm 2.92$ & -3.015 & $0.005^{\star}$ \\
\hline & $\operatorname{TrA}$ & $12.53 \pm 6.50$ & $11.92 \pm 7.75$ & -0.271 & 0.778 \\
\hline & RF & $19.12 \pm 9.16$ & $6.35 \pm 5.76$ & -5.279 & $0.001^{*}$ \\
\hline & $\mathrm{BF}$ & $7.90 \pm 4.28$ & $3.92 \pm 3.59$ & -3.194 & $0.003^{*}$ \\
\hline & GCM & $7.75 \pm 6.68$ & $6.12 \pm 7.01$ & -0.756 & 0.455 \\
\hline & $\mathrm{TA}$ & $12.17 \pm 8.55$ & $2.69 \pm 2.21$ & -4.797 & $0.001^{*}$ \\
\hline \multirow[t]{7}{*}{ Down60 } & MT & $30.86 \pm 11.60$ & $31.86 \pm 15.40$ & 0.231 & 0.819 \\
\hline & ES & $25.07 \pm 11.82$ & $30.35 \pm 10.89$ & 1.470 & 0.150 \\
\hline & $\operatorname{TrA}$ & $13.62 \pm 5.95$ & $9.27 \pm 5.56$ & -2.390 & $0.022^{*}$ \\
\hline & RF & $54.39 \pm 20.39$ & $47.72 \pm 20.63$ & -1.028 & 0.310 \\
\hline & $\mathrm{BF}$ & $17.95 \pm 12.50$ & $9.87 \pm 4.59$ & -2.713 & $0.010^{*}$ \\
\hline & GCM & $14.47 \pm 13.21$ & $3.45 \pm 1.59$ & -3.706 & $0.001^{*}$ \\
\hline & TA & $44.95 \pm 19.20$ & $34.78 \pm 18.08$ & -1.725 & 0.093 \\
\hline \multirow[t]{7}{*}{ Full } & MT & $7.93 \pm 7.75$ & $30.52 \pm 14.78$ & 6.052 & $0.001^{*}$ \\
\hline & ES & $4.92 \pm 2.89$ & $35.61 \pm 14.53$ & 9.261 & $0.001^{*}$ \\
\hline & $\operatorname{TrA}$ & $8.66 \pm 8.20$ & $9.24 \pm 5.68$ & 0.262 & 0.794 \\
\hline & RF & $3.37 \pm 1.96$ & $65.12 \pm 26.46$ & 10.411 & $0.001^{*}$ \\
\hline & $\mathrm{BF}$ & $4.71 \pm 3.76$ & $11.35 \pm 6.76$ & 3.844 & $0.001^{*}$ \\
\hline & GCM & $3.31 \pm 3.19$ & $4.82 \pm 2.88$ & 1.566 & 0.126 \\
\hline & TA & $3.40 \pm 3.73$ & $57.05 \pm 20.94$ & 11.278 & $0.001^{*}$ \\
\hline \multirow[t]{7}{*}{ Up60 } & MT & $55.40 \pm 22.25$ & $42.75 \pm 17.83$ & -1.983 & $0.055^{*}$ \\
\hline & ES & $49.26 \pm 19.85$ & $34.59 \pm 13.03$ & -2.764 & $0.009^{*}$ \\
\hline & $\operatorname{TrA}$ & $27.65 \pm 17.90$ & $13.40 \pm 7.17$ & -3.303 & $0.002^{*}$ \\
\hline & RF & $84.23 \pm 19.47$ & $69.11 \pm 26.28$ & -2.067 & $0.046^{*}$ \\
\hline & $\mathrm{BF}$ & $28.44 \pm 17.71$ & $14.59 \pm 6.32$ & -3.294 & $0.002^{*}$ \\
\hline & GCM & $33.96 \pm 25.54$ & $5.10 \pm 4.97$ & -4.960 & $0.001^{*}$ \\
\hline & TA & $47.99 \pm 26.75$ & $23.41 \pm 12.65$ & -3.715 & $0.001^{*}$ \\
\hline \multirow[t]{7}{*}{ End } & MT & $23.81 \pm 12.38$ & $13.87 \pm 5.58$ & -3.296 & $0.002^{*}$ \\
\hline & ES & $11.18 \pm 6.33$ & $8.23 \pm 4.14$ & -1.748 & 0.089 \\
\hline & TrA & $12.67 \pm 7.16$ & $10.59 \pm 6.64$ & -0.951 & 0.347 \\
\hline & RF & $22.20 \pm 14.54$ & $6.78 \pm 6.17$ & -4.367 & $0.001^{*}$ \\
\hline & $\mathrm{BF}$ & $9.02 \pm 7.44$ & $5.22 \pm 3.68$ & -2.048 & $0.048^{*}$ \\
\hline & GCM & $9.88 \pm 9.66$ & $5.54 \pm 6.49$ & -1.668 & 0.104 \\
\hline & TA & $11.46 \pm 9.68$ & $2.64 \pm 2.42$ & -3.951 & $0.001^{*}$ \\
\hline
\end{tabular}

Values are presented as mean \pm standard deviation.

Start: start period, Down60 : mid-flexion period, Full: final flexion period, Up60: mid-extension period, End: end period, MT: multifidus, ES: elector spinae, TrA: transverse abdominis, RF: rectus femoris, BF: biceps femoris, GCM: gastrocnemius, TA: tibialis anterior. $* p<0.05$

비복근의 근력강화에 탁월한 효과를 보인다고 하였다. ${ }^{13} \mathrm{Kim}{ }^{14}$ 은 피 트니스 공을 대고 벽 미끄러짐 쪼그려 앉기를 수행했을 때 외측광근 근 활성도는 변화 없고, 내측광근과 대퇴직근의 근 활성도는 유의하 게 증가한다고 하였다. 이것은 스쿼트 운동에 따라 내측광근이 민감 하게 반응한다고 설명할 수 있다.15

현재까지 보고된 절 운동 관련 선행연구에서는 복부비만과 뇌파 변화에 대한 절 운동의 효과를 보고하였을 뿐 근 활성도나 운동역학 적 측면의 연구는 이루어지지 않았다. ${ }^{16,17}$ 따라서 본 연구에서는 두 가
지 닫힌사슬 운동인 절 운동과 스쿼트 동작 시 구간별 체간과 하지 의 근 활성도를 조사하여 건강인과 환자에게 적용할 수 있는 운동방 법에 대한 기초자료를 제공하기 위하여 실시하였다.

\section{연구방법}

\section{1. 연구대상}

본 연구는 D대학교에 재학 중인 건강한 20 대 젊은 여성 20 명을 대상 
으로 실시하였다. 연구 대상자의 일반적 특성은 평균 나이 $21.65 \pm$ 0.75 세, 키 $161.21 \pm 4.65 \mathrm{~cm}$, 몸무게 $51.62 \pm 6.24 \mathrm{~kg}$ 이었다.

모든 연구 대상자는 실험 전에 본 연구에 대한 목적과 운동방법에 대한 설명을 듣고 실험에 동의하였으며, 연구 참여 동의서에 서명하 였다. 연구대상자들의 선정 기준은 1) 척추와 하지의 관절가동 범위 에 제한이 없는 자, 2) 실험 참여 시점에서 과거 6개월 동안 하지 관절 에 통증이 없는 자, 3) 최근 6개월 이내에 하지 관절에 대한 근력 강화 운동을 하지 않은 자, 4) 하지 관절에 질환이 없는 자의 조건을 모두 충족하는 자로 하였다.

\section{2. 실험방법}

1) 측정도구

(1) 표면근전도

Desk DTS EMG system (Noraxon inc, Scottsdale, AZ, USA, 2007)을 이 용하여 절운동과 스쿼트 동작 시 구간별 근전도 신호를 수집하였다. 전극의 부착부위는 가는 사포로 문질러 피부각질을 제거하고 알코 올로 소독 후 $2.5 \mathrm{~cm}$ 이하 간격으로 근 섬유와 평행하게 부착하였다. 전극은 일회용 $\mathrm{Ag} / \mathrm{AgCl}$ wet-gel exectrode (Blue Sensor, Medicotest, Olstykke, Denmark)를 사용하였다. 자료 분석은 Noraxon MyoResearch software 3.6을 사용하여 분석하였다. 근전도 신호의 표본추출률 (sampling rate)은 $1,024 \mathrm{~Hz}, 10-450 \mathrm{~Hz}$ 의 Band pass filter를 사용하였으 며, 완파정류(full wave rectification) 처리 후 제곱 평균 제곱근법(root mean square, RMS)으로 처리하여 아스키 형태로 전환하여 분석하였 다. 각각의 측정 근육은 최대근력수축(maximum voluntary isometric contraction, MVIC)으로 정량화하여 $100 \% \mathrm{MVIC}$ 값으로 사용하였다.

\section{2)실험방법}

(1) 근전도 전극 부착 위치 및 정규화

절운동과 스쿼트 동작 중 체간과 하지의 구간별 근 활성도를 알아보 기 위해 기존 연구들을 참조하여 각 근육의 전극 부착 위치를 결정하 였다. 전극 부착 위치는 선행논문을 참조하여 우측의 다열근(multifidus, MT), 척추기립근(L2 elector spinae, ES), 복횡근(transvers abdominis, $\operatorname{TrA}$ ), 대퇴직근(rectus femoris, RF), 대퇴이두근(biceps femoris, $\mathrm{BF}$ ), 비복근(gastrocnemius, $\mathrm{GCM}$ ), 전경골근(tibialis anterior, TA)에 표면전 극을 부착하였다. ${ }^{18}$ 정규화를 위한 최대 등척성 수축 시 대상자의 자 세는 도수근력검사자세에서 시행되었다. 각 근육의 최대 등척성 수 축 시 근 활성도를 3 회 반복 측정하였으며, 5 초 동안 자료 값을 RMS 처리한 후 처음과 마지막 1 초를 제외한 3 초 동안의 평균 근전도 신호 량을 $100 \% \mathrm{MVIC}$ 로 사용하였다.

\section{(2)실험과정}

모든 연구 대상자에게 두 가지 조건 즉, 절 운동과 스쿼트 동작에서 구 간별 근활성도를 비교하기 위하여 5 구간으로 연구자가 동작을 조작 적으로 정의하였다. 절 운동: (1) 시작, (2) 중간 굽힘 구간(내림 구간에서
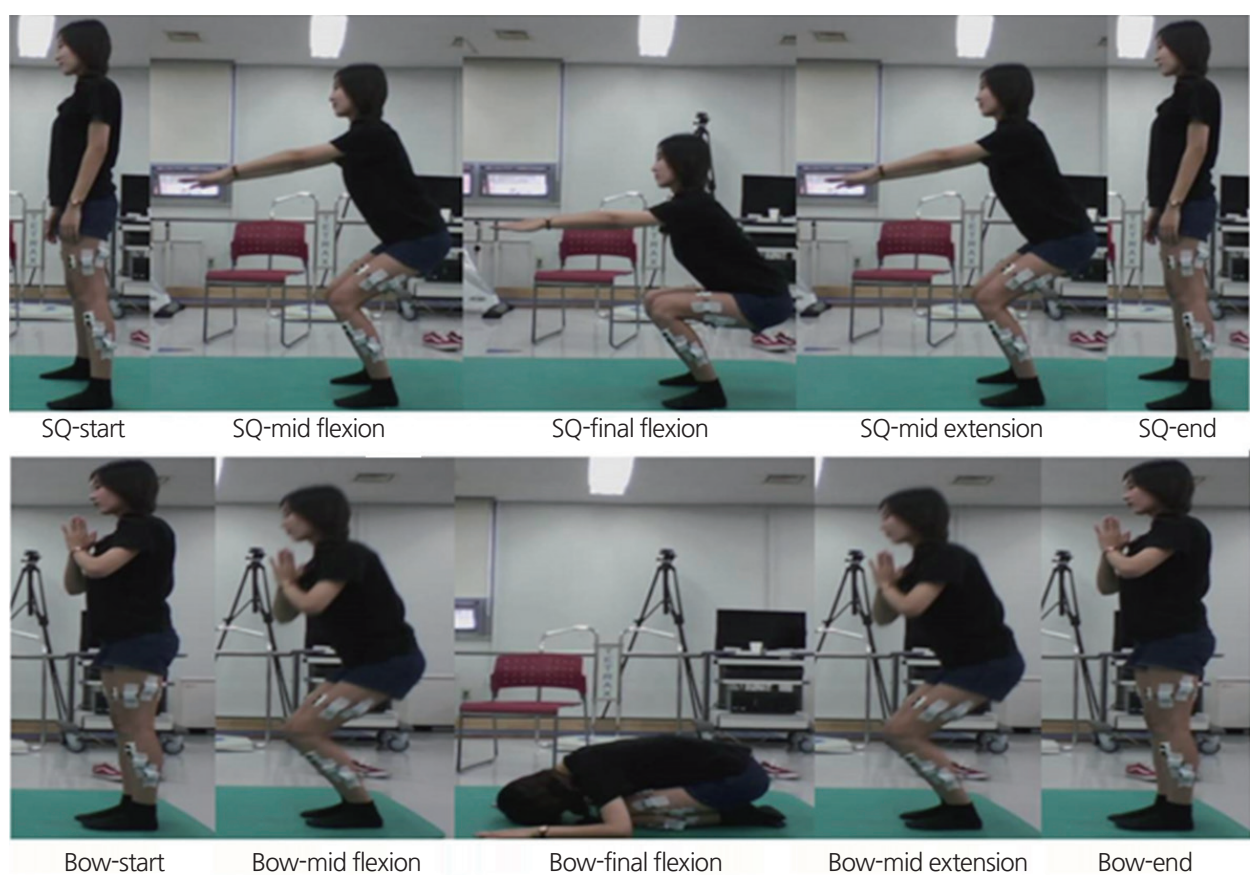

Figure 1. Representative pictures showing each period of both squat (top panel) and bow (bottom panel) exercises. Each exercise is divided into five periods including start, mid flexion, final flexion, mid extension, and end periods. 
슬관절 $60^{\circ}$ 시점), (3) 마지막 굽힘 구간(이마와 양 전완 및 정강이가 바 닥에 닿아 있는 시점), (4) 중간 폄 구간(오름구간에서 슬관절이 $60^{\circ}$ 시 점), (5) 종료, 스쿼트: (1) 시작, (2) 중간 굽힘 구간(내림구간에서 슬관절 $60^{\circ}$ 시점), (3) 마지막 굽힘 구간(대퇴와 슬관절이 $90-100^{\circ}$ 가 되는 시점), (4) 중간 폄 구간(오름구간에서 슬관절이 $60^{\circ}$ 시점), (5) 종료 시점으로 정하였다(Figure 1). 선행연구에서 무릎관절 각도가 $60^{\circ}$ 각도로 닫힌사 슬 운동수행 시 가장 높은 근활성도가 보고되어 이를 근거로 하였다. ${ }^{19}$

\section{(3) 스쿼트와 절 운동 방법}

본 연구에서는 운동 실시 전 대상자들에게 스쿼트와 절 운동에 대한 영상을 보여주고 구두 지시와 시범을 통한 5분 동안의 익숙화(familiarization) 과정을 가졌으며, 각 구간별 동작 속도는 메트로놈(40 beat/ $\mathrm{min}$ )으로 통제하였다. 스쿼트와 절 운동 동작은 각각 3 회씩 반복하 여 실시하였으며 대상자의 근 피로를 최소화하기 위해 같은 동작 사 이, 다른 동작 사이에 매번 3 분의 휴식시간을 주었다.

스쿼트 운동은 선 자세에서 양발을 어깨 넓이로 벌리고 시선은 정 면을 응시하게 하였으며, 대상자는 근전도의 비프 음(beeper)이 울리 는 동시에 3 초 동안 정적으로 선 자세를 유지한 후 다시 비프 음이 울 리면 슬관절을 굴곡시켜 관절각도계 측정 $60^{\circ}$ 에 이르는 시점에서 3 초 동안 유지하도록 하였다. 이어 다음 비프 음이 울리면 최종 굽힘 상태에서 3 초간 유지한 다음 다시 슬관절이 $60^{\circ}$ 에 이를 때까지 일어 서게 하여 3 초간 유지 후 직립상태로 완전 일어서게 하였다.

절 운동의 시작 자세는 선 자세에서 양발을 모아 서게 하고, 시선은 정면을 응시하며 두 손을 가슴 앞에서 합장하게 하였다. 근전도의 비 프 음이 울리는 동시에 합장 자세에서 허리를 반듯이 펴고 슬관절을 굴곡시켜 관절각도계 측정 $60^{\circ}$ 에 이르는 시점에서 3 초간 유지하도록 하였다. 다시 비프 음이 울리면 합장한 손은 앞쪽으로 어깨 넓이만큼 벌려 짚고, 몸통은 살짝 앞으로 기울였다. 이어 팔꿈치를 굽히고 양 팔과 정강이, 이마가 바닥에 닿으며, 왼발은 오른발 위로 포갠 후 엉덩 이는 뒤꿈치 사이로 앉아 3 초 동안 머물렀다. 이어 비프 음이 울리면 손을 짚고 머리를 들며 팔꿈치를 펴서 몸이 약간 앞으로 나아가고, 동 시에 발가락을 세워 일어나게 하여 슬관절이 $60^{\circ}$ 이르는 지점에서 3 초간 유지한 후 직립상태로 완전히 일어서게 하였다.

\section{3. 자료분석}

통계학적 분석은 SPSS version 18.0을 사용하였다. KolmogorovSmirnov 검정으로 대상자의 일반적 특성의 정규분포를 확인하고, independent t-test로 절 운동과 스쿼트 동작 시 구간별 체간과 하지의 근 활성도를 비교 분석하였다. 통계적 유의성을 검증하기 위한 유의 수준은 $\alpha=0.05$ 로 하였다.

\section{결 과}

\section{1. 절 운동과 스쿼트 동작의 시작시점과 중간 굽힘 구간에서의 근 활성도 비교}

두 동작의 시작 시점에서 절 운동 시 다열근(MT), 척추기립근(ES), 그 리고 하지 대퇴직근(RF), 대퇴이두근(BF), 전경골근(TA)에서 근 활성 도가 유의하게 높았다 $(\mathrm{p}<0.05)$. 두 동작의 중간 굽힘 구간에서 절 운 동 시 복횡근 $(\operatorname{Tr} \mathrm{A})$, 대퇴이두근(BF), 비복근 $(\mathrm{GCM})$ 의 근 활성도가 유 의하게 높았다 $(\mathrm{p}<0.05)$ (Table 1$)$.

\section{2. 절 운동과 스쿼트 동작의 마지막 굽힘 구간에서의 근 활성도 비교} 두 동작의 마지막 굽힘 구간에서 스쿼트 동작 시 다열근(MT), 척추기 립근 $(\mathrm{ES})$, 대퇴직근 $(\mathrm{RF})$, 대퇴이두근 $(\mathrm{BF})$, 전경골근 $(\mathrm{TA})$ 에서 근 활성 도가 유의하게 높았다 $(\mathrm{p}<0.05)$ (Table 1).

\section{3. 절 운동과 스쿼트 동작의 중간 폄 구간과 종료 시점에서의 근활성도 비교}

두 동작의 중간 폄 구간에서는 절 운동 시 다열근(MT), 척추기립근 $(\mathrm{ES})$, 복횡근 $(\mathrm{TrA})$, 대퇴직근 $(\mathrm{RF})$, 대퇴이두근(BF), 비복근 $(\mathrm{GCM})$, 전경 골근(TA)에서 근 활성도가 유의하게 높았다 $(\mathrm{p}<0.05)$.

두 동작의 종료 시점에서의 체간과 하지의 근 활성도는 절 운동 동 작 시 다열근(MT), 대퇴직근(RF), 대퇴이두근(BF), 전경골근(TA)에서 근 활성도가 유의하게 높았다 $(\mathrm{p}<0.05)$ (Table 1).

\section{고 찰}

본 연구는 스쿼트와 108 배 절 운동 시 체간과 하지에서의 근활성도 를 비교하여 건강인과 환자에게 선택적으로 적용할 수 있는 근력강 화 운동프로그램 고안에 기초자료를 제공하기 위하여 실시하였다. 스쿼트와 절 운동을 각각 내려가는 구간인 편심성 구간과 올라가는 구간인 동심성의 5 구간으로 나누어 근 활성도를 비교하였다. 본 연구 결과 두 동작의 시작 시점에서는 절 운동 시 다열근, 척추기립근, 대퇴 직근, 대퇴이두근, 전경골근에서, 중간 굽힘 구간에서는 절 운동 시 복횡근, 대퇴이두근, 비복근의 근 활성도가 유의하게 높았다 $(\mathrm{p}<0.05)$. 또 마지막 굽힘 구간에서는 스쿼트 동작 시 다열근, 척추기 립근, 대퇴직근, 대퇴이두근, 전경골근이, 중간 폄 구간에서는 절 운 동 시 다열근, 척추기립근, 복횡근, 대퇴직근, 대퇴이두근, 비복근, 전 경골근에서, 종료 시점에서는 절 운동 동작 시 다열근, 대퇴직근, 대퇴 이두근, 전경골근에서 근 활성도가 유의하게 높았다 $(\mathrm{p}<0.05)$.

본 연구에서 절 운동의 시작 시점에서 다열근, 척추기립근, 대퇴직 근, 대퇴이두근, 전경골근에서 스쿼트 동작보다 근 활성도가 유의하 
게 높게 나타난 것은 스쿼트 시 직립 위치에서 압력중심(center of pressure)과 무릎 및 발목관절 토크에 작은 변화를 보고한 연구와 일 치하였다. ${ }^{20}$ 또한 스쿼트를 시작하는 운동전략의 다양성에 대한 설명 으로 상지와 하지의 위치 차이와 관련될 수 있다고 하였다. ${ }^{21}$ 본 연구 에서 두 동작의 시작 자세의 차이는 즉, 절 운동에서는 양 발을 모으 고 직립하여 양손을 합장한 상태이며, 스쿼트 동작에서는 양팔을 내 리고 양 발을 어깨 넓이로 벌려 직립한 상태이기 때문으로 생각된다. 또한 평형을 방해하고 스쿼트를 개시하기 위한 중추신경계의 예비반 응으로 스쿼트에 앞서 슬괵근과 척추기립근의 감소된 근활성도와 전 경골근의 증가된 근 활성을 보고하였다.22-24 Dionisio 등 20 은 스쿼트 준비단계에서 슬괵근과 대퇴사두근의 근활성도는 변화가 없었으며, 전경골근의 증가된 근활성도를 보고하였다. 스쿼트와 절 운동 동작 은 모두 좌-우보다는 전-후 방향의 움직임이 큰 동작이며,20,25 상대적 으로 전-후 방향의 움직임이 큰 절 운동에서 전경골근의 높은 근활 성도를 나타낸 것으로 생각된다.

본 연구결과 절 운동의 중간 굽힘 구간에서 복횡근, 대퇴이두근, 비 복근의 근활성도가 스쿼트 동작의 중간 굽힘 구간보다 유의하게 높 게 나타났다. 압력중심이 후방으로 이동하는 스쿼트의 가속단계 즉, 내림구간에서의 슬관절 토크는 굽힘되어 있어 측정 가능한 근 활성 도가 없다고 하였다. ${ }^{20}$ 본 연구에서도 슬관절 신전근육인 대퇴직근의 근 활성도는 차이가 없었다. 또한 중간 굽힘 구간의 절 운동에서는 양 손을 합장하고 있으며, 스쿼트 동작에서는 팔을 수평으로 그리고 전 방으로 $90^{\circ}$ 거상하고 있다. 그러므로 양손 합장과 함께 스쿼트 동작보 다 체간을 더 굴곡하고 있는 절 운동에서 복근을 좀 더 강하게 수축 할 수 있었을 것으로 사료된다. 또한 복근 중 자세동요에 유일하게 작 용하는 근육이 복횡근이다. ${ }^{2}$ 따라서 좀 더 역동적인 절 운동에서 복 횡근이 더 큰 근 활성도를 나타냈을 것으로 생각한다.

연구 결과 스쿼트 동작의 마지막 굽힘 구간에서는 다열근, 척추기 립근, 대퇴직근, 대퇴이두근, 전경골근에서 절 운동보다 근활성도가 유의하게 높게 나타났다. 스쿼트 마지막 굽힘 구간은 가속구간으로 신체가 후방으로 넘어지는 것을 방지하기 위하여 비복근과 전경골 근은 동시 활성화되어 강한 반발력을 받는 발목관절에 안정성을 제 공한다고 하였다. ${ }^{20}$ 반면 절 운동의 마지막 굽힘 구간은 정강뼈 부위 가 바닥에 닿아 스쿼트 보다 상대적으로 안정적이어서 낮은 근활성 도를 나타낸 것으로 생각된다.

중간 폄 구간에서는 절 운동 시 다열근, 척추기립근, 복횡근, 대퇴직 근, 대퇴이두근, 비복근, 전경골근에서 스쿼트 동작보다 근활성도가 유의하게 높게 나타났다. 스쿼트의 중간 폄 구간은 감속기로 편심성 으로 작용하는 대퇴사두근의 강한 활성에 의해 생성된다. ${ }^{20}$ 한편 대퇴 이두근의 근 활성도의 작은 증가는 과도한 고관절 굴곡을 피하고 골 반을 안정시키며, 무릎 안정성에 도움을 준다고 하였다. 대퇴사두근
과 슬괵근 근활성은 특별히 높은 무릎 굴곡 각도에서 나타난다고 하 였다.26,27 또한 스쿼트보다 런지(lunging) 시 더 큰 외측광근의 활성이 보고되었다. ${ }^{28}$ 이것은 런지에서 더 많은 근육의 힘이 필요하다는 것을 시사한다. 본 연구에서도 대퇴직근과 슬괵근에서 근 활성도가 증가 하였다. 이것은 절 운동이 스쿼트보다 대퇴사두근의 강한 활성을 끌 어낼 수 있음을 의미한다. 본 연구 결과만을 놓고 볼 때 스쿼트 동작보 다 더 큰 운동범위를 가진 절 운동의 올라가는 구간인 중간 폄 구간에 서 체간과 하지의 근육에서 근 활성도가 유의하게 높게 나타났다고 설명할 수 있다. 이러한 소견은 증가된 근활성을 유발하기 위한 하지 힘 생산능력을 증가시키기 위한 운동프로그램 고안에 중요할 것이다.

종료 시점에서도 역시 절 운동에서 다열근, 대퇴직근, 대퇴이두근, 전경골근에서 근활성도가 유의하게 높게 나타났다. 이전 연구에서 스쿼트의 최종 위치에서 낮은 대퇴사두근의 근활성과 무릎관절 토 크를 보였다. ${ }^{20}$ 본 연구에서도 유사한 결과를 보였으며, 스쿼트 운동 의 종료시점보다 절 운동의 종료시점에서 높은 근 활성도를 보였다. 이것은 스쿼트 동작보다 상대적으로 좁은 기저면에서 편심성 수축 을 요구하는 절 운동에서 무릎 신전근의 요구가 크기 때문이라고 사 료된다. 또한 절 운동 동작은 스쿼트와 비교하여 상대적으로 큰 관절 가동범위가 요구되며, 신체 중심의 이동 또한 넓어 불안정성이 증가 할 수 있다. 따라서 스쿼트 동작 시 보다 높은 근 활성도와 안정성이 요구된다고 할 수 있다.

본 연구에서 절 운동의 마지막 굽힘 구간을 제외한 시작 시점, 중간 굽힘 구간, 중간 폄 구간, 종료 시점에서 체간과 하지에 위치한 대부분 의 근육들에서 근 활성도가 높게 나타났다. 이상의 결과를 종합해보 면 절 운동에서 마지막 굽힘 구간을 제외하고 모든 구간에서 체간과 하지의 대부분 근육에서 높은 근활성도를 나타냈다. 따라서 절 운동 은 스쿼트 운동보다 건강인과 환자의 체간과 하지의 근력강화 운동 으로 적합할 것으로 생각된다. 그러나 본 연구는 1) 적은 연구대상자 수와 20 대 여성들만을 선정하여 성별이나 연령에 따른 결과를 고려 하지 못했다. 2) 절 운동 시 하지 후면의 전극 노이즈 발생으로 인한 근 전도 신호량 수집에 오류가 발생할 수 있어 본 연구 결과의 일반화와 관련하여 제한점이 될 수 있다. 3) 선행 연구에서는 내측광근과 대퇴 직근의 활성도를 알아보았으나 본 연구에서는 내측광근을 대상으로 하지 않아 이전 연구와 다양한 비교가 어렵다는 것이다. ${ }^{14}$ 이에 향후 연구에서는 본 연구의 제한점을 보완하여 여성뿐만 아니라 남성, 다 른 하지의 주요 근육, 다양한 연령을 대상으로 한 운동형상학적, 운동 역학적, 생리학적 분석이 필요할 것이라 생각된다.

\section{REFERENCES}

1. Escamilla RF. Knee biomechanicsof the dynamic squat exercise. Med Sci 
Sports Exerc. 2001;33(1):127-41.

2. Kisner C, Colby LA. Therapeutic exercise: Foundations and techniques. 6th ed. Philadelphia, F.A Davis, 2012:186-92.

3. Donatelli RA. Abnormal biomechanics of the foot and ankle. J Orthop Sports Phys Ther. 1987;9(1):11-6.

4. McGinty G, Irrgang JJ, Pezzullo D. Biomechanical considerations for rehabilitation of the knee. Clin Biomech. 2000;15(3):160-6.

5. Irrgang JJ. Modern trends in anterior cruciate ligament rehabilitation: Nonoperative and postoperative management. Clin Sports Med. 1993; 12(4):797-813.

6. Mangine RE, Noyes FR. Rehabilitation of the allograft reconstruction. J Orthop Sports Phys Ther. 1992;15(6):294-302.

7. Shelbourne KD, Nitz P. Accelerated rehabilitation after anterior cruciate ligament reconstruction. J Orthop Sports Phys Ther. 1992;15(6):256-64.

8. Wilk KE, Andrews JR. Current concepts in the treatment of anterior cruciate ligament disruption. J Orthop Sports Phys Ther. 1992;15(6): 279-93.

9. Jan $\mathrm{MH}$, Lin $\mathrm{CH}$, Lin YF et al. Effects of weight-bearing versus nonweight bearing exercise on function, walking speed, and position sense in participants with knee osteoarthritis: A randomized controlled trial. Arch Phys Med Rehabil. 2009;90(6):897-904.

10. Nobre TL. Comparison of exercise open kinetic chain and closed kinetic chain in the rehabilitation of patellofemoral dysfunction: An updated revision. Clinical Medicine and Diagnostics. 2012;2(3):7-11.

11. Balci P, Tunay VB, Baltaci G et al. The effects of two different closed kinetic chain exercises on muscle strength and proprioception in patients with patellofemoral pain syndrome. Acta Orthop Traumatol Turc. 2009;43(5):419-25.

12. Tagesson S, Oberg B, Good L et al. A comprehensive rehabilitation program with quadriceps strengthening in closed versus open kinetic chain exercise in patients with anterior cruciate ligament deficiency: A randomized clinical trial evaluating dynamic tibial translation and muscle function. Am J Sports Med. 2008;36(2):298-307.

13. Consitt LA, Copeland JL, Tremblay MS. Endogenous anabolic hormone responses to endurance versus resistance exercise and training in women. Sports Med. 2002;32(1):1-22.

14. Kim BJ. Comparison of quadriceps femoris muscle activation during wall slide squats. Korean Soc Phys Med. 2012;7(4):541-50.

15. Oh TY. The Effects of Squatting Exercise with Gym Ball and Wall on Lower Extremity Muscles Activation. Korean Soc Phys Med. 2013;
8(4):647-53.

16. Lee HW, Park JH. The effects of an 8 week 108 bows-training on the consistency and variation in electroencephalographic patterns during golf putting. Journal of Sports and Leisure Studies. 2013;53(1):549-56.

17. Cheong KJ, Oh JY, Park SS et al. The effect of 108 obeisance on reduction of the abdominal obesity. Korean Journal of Exercise Rehabilitation. 2009;5(1):29-38.

18. Yoon TL, Kim KS, Cynn HS. Slow expiration reduces sternocleidomastoid activity and increases transversus abdominis and internal oblique muscle activity during abdominal curl-up. J Electromyogr Kinesiol. 2014;24(2):228-32.

19. Tang SF, Chen CK, Hsu R et al. Vastus medialis obliquus and vastus lateralis activity in open and closed kinetic chain exercises in patients with patellofemoral pain syndrome: An electromyographic study. Arch Phys Med Rehabil. 2001;82(10):1441-5.

20. Dionisio VC, Almeida GL, Duarte M et al. Kinematic, kinetic and EMG patterns during downward squatting. J Electromyogr Kinesiol. 2008; 18(1):134-43.

21. Hase K, Sako M, Ushiba J et al. Motor strategies for initiating downwardoriented movements during standing in adults. Exp Brain Res. 2004; 158(1):18-27.

22. Fredericson M, Powers C. Practical management of patellofemoral pain. Clin J Sport Med 2002;12(1):36-8.

23. Cheron G, Bengoetxea A, Pozzo T et al. Evidence of a preprogrammed deactivation of the hamstring muscles for triggering rapid changes of posture in humans. Electroencephalogr Clin Neurophysiol. 1997;105(1): 58-71.

24. Dan B, Bouillot E, Bengoetxea A et al. Adaptive motor strategy for squatting in spastic diplegia. Eur J Paediatr Neurol. 1999;3(4):159-65.

25. Kim MJ, Lee HC, Park JW. The Effect of Additional Haptic Supplementation on Postural Control During Squat in Normal Adult. J Kor Phys Ther. 2012;24(2):134-42.

26. Ebben WP, Feldmann CR, Dayne A et al. Muscle activation during lower body resistance training. Int J Sports Med. 2009;30(1):1-8.

27. Stuart MJ, Meglan DA, Lutz GE et al. Comparison of intersegmental tibiofemoral joint forces and muscle activity during various closed kinetic chain exercises. Am J Sports Med. 1996;24(6):792-9.

28. Longpré HS, Acker SM, Maly MR. Muscle activation and knee biomechanics during squatting and lunging after lower extremity fatigue in healthy young women. J Electromyogr Kinesiol. 2015;25(1):40-6. 